\title{
ANALISIS PENYELESAIAN TINDAK LANJUT HASIL PEMERIKSAAN
}

\author{
Lusiana, Ali Djamhuri, \& Yeney Widya Prihatiningtias \\ Universitas Brawijaya, Indonesia \\ Email: lushiechand@gmail.com
}

\begin{abstract}
Abstrak: Analisis Penyelesaian Tindak Lanjut Hasil Pemeriksaan. Penelitian ini bertujuan untuk menjelaskan proses penyelesaian Tindak Lanjut Hasil Pemeriksaan di Pemerintah Kabupaten Sanggau melalui pelaksanaan fungsi-fungsi manajemen (perencanaan, penggorganisasian, pengarahan, dan pengendalian) sebagai alat analisisnya, dan mengidentifikasi permasalahan yang menyebabkan belum optimalnya penyelesaian TLHP. Penelitian ini menggunakan pendekatan kualitatif dengan model studi kasus dan difokuskan pada Organisasi Perangkat Daerah (OPD) yang masih memiliki temuan yang belum tuntas. Informan yang dipilih, yaitu pimpinan OPD, salah satu pejabat teknis yang menangani TLHP dan salah satu pejabat Inspektorat daerah. Hasil penelitian menunjukkan terdapat kelemahan dalam proses penyelesaian TLHP yang menyebabkan penyelesaian TLHP belum optimal, yaitu belum tersedianya kebijakan khusus tentang TLHP; lambatnya respon pihak lain dalam proses koordinasi dan belum intensifnya koordinasi antara OPD dan lembaga pengawasan; pimpinan belum mampu memberikan motivasi; kurangnya komitmen pimpinan; kesulitan dalam melakukan proses evaluasi dan tidak dilaksanakan evaluasi secara berkala; belum optimalnya peran Majelis Pertimbangan TPTGR; dan kendala-kendala teknis yang dihadapi oleh OPD.
\end{abstract}

Kata Kunci: TLHP, Fungsi Manajemen, Perencanaan, Pengorganisasian, Pengarahan, Pengendalian.

Abstract: Analysis of Follow up Audit. This study aimed to explain the process of follow up audit in Sanggau local government by using management functions (planning, organizing, directing, and controlling) as the analysis instrument and identify problems that caused follow up audit was not optimal. This study used a qualitative approach with case study model and focused on OPD that still have unfinished findings. The selected informant is the Head of OPD; a technical official handling follows up audit and an Inspectorate official. The results of the study showed that there were some weaknesses in the process of follow up audit. For example, there was no specific policy about follow up audit, the slow responses of other parties in the process of coordination and the coordination between OPD and monitoring institution was not intensive; the leader was not able to give motivation, the low commitment of the leader, Difficulties in the evaluation process and the evaluation was not periodically, the role of TPTGR Assembly Consideration was not optimal, and the technical obstacles that was faced by OPD.

Keyword: follow up audit, management function, planning, organizing, directing, controlling.

\section{PENDAHULUAN}

Dalam konteks manajemen, auditing sebagai fungsi pengawasan (controlling) terhadap keseluruhan fungsi-fungsi lainnya yaitu perencanaan (planning), pengorganisasian (organizing), dan pengarahan (directing). Fungsi pengawasan dalam penyelenggaraan pemerintahan sangatlah penting baik sebagai early warning system apabila terdapat penyimpangan maupun sebagai 
fungsi pembinaan bagi satuan kerja di setiap unit pemerintahan. Pada pemerintahan, istilah pemeriksaan sering digunakan sebagai terjemahan dari auditing (BPKP,2009). Audit merupakan proses kritis yang dapat membantu mengidentifikasi kelemahan yang ada serta mengidentifikasi setiap peluang perkembangan yang terbuka (Kaelin, 2016).

Setelah melakukan pemeriksaan maka auditor akan menerbitkan dokumen hasil pemeriksaan yang disebut dengan Laporan Hasil Pemeriksaan (LHP) yang berisi hasil audit dan rekomendasi auditor yang harus ditindaklanjuti oleh auditi. Rekomendasi hasil pemeriksaan bermanfaat untuk perbaikan kinerja organisasi auditi. Tindak Lanjut Hasil Pemeriksaan (TLHP) merupakan aktivitas auditi dalam rangka memenuhi rekomendasi auditor yang tertuang dalam hasil pemeriksaan.

Banyak anggapan yang mengira bahwa penerbitan LHP merupakan akhir dari kegiatan pemeriksaan dan merupakan akhir keterlibatan auditor, padahal hasil atau manfaat penuh dari proses audit sendiri berupa perbaikan berdasarkan kesalahan yang telah diidentifikasikan baru akan dirasakan oleh auditi jika temuan audit telah ditindaklanjuti (Russell \& Regel,1996). Sementara Liu \& Lin (2012) juga menyebutkan bahwa perbaikan setelah proses Audit dapat meningkatkan akuntabilitas objek pemeriksaan. Aikins (2012) menyarankan agar pemerintah daerah meningkatkan monitoring dan melaksanakan tindak lanjut rekomendasi temuan audit dalam rangka memperkuat akuntabilitas publik. Schneider (2009) menjelaskan bahwa pelaksanaan rekomendasi audit merupakan salah satu bentuk dukungan dari auditi terhadap keberhasilan fungsi audit.

Oleh sebab itu, saran atau rekomendasi hasil pemeriksaan seharusnya tidak hanya ditindaklanjuti secara administrasi saja tetapi harus dilaksanakan sungguh-sungguh untuk memperbaiki sistem pengendalian intern yang ada, sehingga akan mengurangi risiko terjadinya penyimpangan di masa mendatang dan manfaat pengawasan dapat dirasakan secara optimal. Kewajiban menyelesaikan TLHP telah diatur dalam peraturan perundangan, yaitu dalam pasal 23E UUD 1945, pasal 20 Undang-Undang Nomor 15 Tahun 2004, pasal 34 Peraturan Pemerintah Nomor 79 Tahun 2005, Peraturan Menteri Pendayagunaan Aparatur Negara Nomor 9 Tahun 2009 pada bab II, dan Surat Edaran Nomor: SE/02/M.PAN/ 01/2005. Untuk jangka waktu penyelesaian TLHP dilaksanakan selambat-lambatnya 60 (enam puluh) hari kalender sejak diterimanya LHP. Dengan memperhatikan berbagai ketentuan peraturan perundangan, maka jelas bahwa pelaksanaan TLHP merupakan hal yang penting untuk dilaksanakan.

Pemerintah Kabupaten Sanggau dipilih menjadi objek penelitian karena berdasarkan data yang tersedia menunjukkan bahwa jumlah rekomendasi audit yang belum tuntas diselesaikan oleh auditi cukup signifikan. Dari 428 jumlah rekomendasi BPK dari tahun 2007-2017, masih ada 113 rekomendasi yang belum tuntas dengan jumlah pengembalian keuangan yang masih harus disetorkan ke kas daerah sebesar Rp.5.359.534.578. Untuk temuan yang berindikasi terhadap potensi kerugian daerah dan telah mendapat penetapan Kepala Daerah sebagai kerugian daerah, terdapat 69 kasus yang masih belum 
tuntas dengan sisa kerugian yang masih harus dikembalikan ke kas daerah sebesar Rp.2.256.687.825. Secara keseluruhan dari data tersebut menunjukkan pelaksanaan TLHP belum optimal dan adanya ketidakseriusan auditi melaksanakan rekomendasi yang diberikan auditor.

TLHP merupakan kelanjutan dari proses pemeriksaan dan merupakan hal yang penting dan perlu mendapat perhatian khusus karena menentukan efektivitas pengawasan (Benson, 1995 dan Russell \& Regel, 1996), mempengaruhi kinerja dan akuntabilitas organisasi, mendukung penerapan good governance (SE/02/M.PAN/01/2005, Liu \& Lin, 2012, Sari, 2013 dan Suryanto, 2015), mempengaruhi kredibilitas lembaga pengawasan (Keating, 1995), serta merupakan amanat dari peraturan perundang-undangan. Namun, pada kenyataannya terdapat kesenjangan antara yang terjadi dan yang seharusnya, maka hal inilah yang mendorong peneliti ingin melakukan kajian mengenai proses penyelesaian TLHP pada Pemerintah Daerah Kabupaten Sanggau yang terjadi selama ini.

Terdapat beberapa penelitian sebelumnya mengenai permasalahan tindak lanjut hasil audit, antara lain seperti yang telah dilakukan oleh Sidik (2009) Junarlin (2009), Sari (2013), Arini (2014), Suryanto (2015), dan Loke, Ismail \& Hamid (2016). Penelitian-penelitian tersebut menunjukkan bahwa permasalahan serupa juga terjadi di tempat lain, Inspektorat Daerah selaku lembaga pengawasan telah berupaya untuk mendorong penyelesaian TLHP, namun upaya yang dilakukan oleh auditi sebagai lembaga teknis yang berkewajiban menyelesaikan TLHP merupakan hal yang paling menentukan penyelesaiannya. Pada penelitian ini, TLHP yang dimaksud merupakan pelaksanaan rekomendasi hasil pemeriksaan yang dilakukan oleh BPK. Perbedaan dengan penelitian sebelumnya yaitu pada penelitian ini memfokuskan pada upaya penyelesaian TLHP dari sisi auditi dan untuk analisisnya ditinjau menggunakan fungsi manajemen atas proses penanganan tindak lanjut yang dilakukan oleh Organisasi Perangkat Daerah (OPD) yang masih memiliki jumlah pending tindak lanjut yang cukup signifikan. Selanjutnya melalui hasil analisis tersebut diketahui permasalahan yang menjadi penyebab belum optimalnya penyelesaian TLHP di Pemerintah Kabupaten Sanggau.

Manajemen merupakan suatu proses yang terdiri dari perencanaan, pengorganisasian, pengarahan, dan pengendalian yang dilakukan untuk mencapai tujuan dengan memanfaatkan sumber daya (Terry, 1977; Stoner, 1982; dan Newport \& Trewatha, 1976). Pada dasarnya semua jenis manajemen pada setiap organisasi melalui proses yang sama tetapi mungkin dilakukan dengan cara yang berbeda tergantung pada struktur dan jenis organisasi, karakter orang yang bekerja di dalamnya, budaya, faktor situasional dan ketersediaan sumber daya (Qureshi et al., 2013). Proses manajemen tersebut oleh para ahli dibagi ke dalam beberapa fungsi dasar, yang kemudian dikenal dengan sebutan fungsi-fungsi manajemen. Tujuan pembagian tersebut agar sistematika urutan pembahasannya lebih teratur dan supaya lebih mudah dan lebih mendalam saat melakukan analisisnya, serta dapat menjadi 
pedoman pelaksanaan proses manajemen (Hasibuan, 2014).

Fungsi-fungsi manajemen merupakan rangkaian aktivitas dalam manajemen menurut fungsinya masing-masing yang dalam pelaksanaannya mengikuti tahapantahapan tertentu. Dalam penelitian ini, penulis mengkaji proses penyelesaian TLHP yang dilakukan oleh auditi melalui pelaksanaan fungsi-fungsi manajemen pada OPD di Pemerintah Kabupaten Sanggau. Fungsi-fungsi manajemen yang akan digunakan dalam penelitian ini adalah fungsi manajemen menurut Nickels et al., (1997) yaitu fungsi perencanaan (planning), pengorganisasian (organizing), pengarahan (directing), dan pengendalian (controlling).

Dalam proses penyelesaian TLHP, organisasi perlu segera membuat perencanaan (planning) begitu Laporan Hasil Pemeriksaan (LHP) diterima. Perencanaan tersebut mencakup tujuan/sasaran/target yang hendak dicapai, dalam hal ini adalah status penyelesaian TLHP dan perbaikan manajemen. Perencanaan juga mengandung strategi bagaimana pelaksanaan rekomendasi pemeriksaan agar bisa mencapai tujuan tersebut, yaitu melalui cara atau kegiatan tertentu. Dalam perencanaan juga ditentukan mengenai penggunaan sumber daya yang diperlukan, baik berupa SDM maupun dana, alat, dan kebijakan. Hal terakhir yang perlu ditetapkan adalah standar/indikator keberhasilan dalam pencapaian target, hal ini bisa berupa jangka waktu tertentu yang diberikan untuk melaksanakan penyelesaian TLHP.

Setelah perencanaan disusun maka proses berikutnya adalah bagaimana pimpinan memastikan bahwa perencanaan yang telah disusun dapat dilaksanakan, yaitu dengan membagi tugas/pekerjaan kepada individu atau kelompok tertentu secara tepat serta mengalokasikan sumber daya yang diperlukan untuk mendukung pelaksanaannya. Pembagian tugas selalu disertai dengan pendelegasian wewenang dan tanggung jawab dalam batas-batas tertentu. Dalam proses pengorganisasian (organizing), tentunya pimpinan memberikan tugas kepada seseorang atau unit kerja tertentu yang lebih menguasai permasalahan yang dimaksud sesuai dengan bidang tugas dan tanggung jawabnya serta kompetensi yang dimiliki dan apabila harus melibatkan beberapa bidang untuk saling bekerjasama, maka pimpinan perlu mengatur proses koordinasi antar bagian tersebut maupun hubungan dengan pihak ketiga jika diperlukan.

Beberapa hal pokok dalam fungsi pengarahan (directing), yaitu tingkah laku manusia, hubungan manusiawi, komunikasi dan kepemimpinan (Hasibuan, 2014). Dalam hal ini, manajer memainkan peran penting dalam mendukung keberhasilan pengelolaan organisasi yang melibatkan bakat, keterampilan manajerial dan perilaku manajer (Naeemullah et al., 2010). Dalam proses penyelesaian TLHP, fungsi pengarahan yang perlu dilakukan oleh pimpinan antara lain, menjelaskan kepada bawahan bagaimana melaksanakan tugastugas yang diberikan, memberikan bimbingan ataupun konsultasi jika diperlukan, menjelaskan kewajiban pelaksanaan peraturan perundangan dan manfaat pelaksanaan rekomendasi pemeriksaan, dan memberikan motivasi kepada bawahan. 
Pengendalian (controlling) dilaksanakan oleh pimpinan dengan menilai kinerja bawahannya dalam melaksanakan tugastugas yang telah diberikan. Pimpinan melakukan pengendalian bukan hanya pada akhir kegiatan tetapi telah dimulai sejak awal dan dalam proses pengerjaan, hingga menuntut pertanggungjawaban pada akhir kegiatan. Dalam hal penyelesaian TLHP, maka pimpinan perlu memantau pekerjaan bawahannya sudah sejauh mana proses penyelesaian dilakukan, memeriksa apakah sesuai dengan rencana dan jika ditemui kendala-kendala maka mengupayakan mencari solusi yang terbaik.

\section{METODE}

Penelitian ini menggunakan pendekatan kualitatif dengan jenis studi kasus (study case). Peneliti ingin mengetahui informasi yang detail dan lengkap mengenai proses penyelesaian TLHP yang dilakukan oleh auditi dan mengetahui permasalahan yang menyebabkan penyelesaian TLHP belum optimal, informasi ini hanya dapat diperoleh dengan berbicara langsung dengan para pelaksana (Creswell, 2014). Moleong (2014) menyebutkan bahwa penelitian kualitatif bermanfaat untuk keperluan peneliti yang ingin meneliti sesuatu dari segi prosesnya, hal ini sesuai dengan penelitian ini di mana peneliti mengkaji proses penyelesaian TLHP. Peneliti mengumpulkan data di lapangan di mana para informan mengalami masalah yang sedang dikaji dalam penelitian ini, yaitu pada OPD) di Pemerintah Daerah Kabupaten Sanggau, dengan pertimbangan bahwa masih terdapat jumlah pending TLHP yang cukup signifikan.
Data diperoleh dari hasil wawancara, pengamatan, dan dokumentasi. Penentuan informan dalam penelitian ini dilakukan dengan cara purposif (purposive), yaitu pemilihan berdasarkan atas ciri atau sifat tertentu yang dinilai mempunyai keterkaitan dengan ciri atau sifat populasi yang sudah diketahui sebelumnya (Sutrisno, 1983). Peneliti menentukan kriteria mengenai jenis pending rekomendasi yang akan dikaji secara khusus, yaitu:

1. OPD yang memiliki jumlah pending TLHP yang bersifat administrasi paling banyak. Berdasarkan data yang diperoleh, diketahui OPD yang memiliki pending TLHP yang bersifat administrasi paling banyak adalah Dinas Pendidikan dan Kebudayaan. Informan yang dipilih adalah Kepala Dinas Pendidikan dan Kebudayaan dan Kepala Sub Bidang Perencanaan dan Akuntabilitas Kinerja.

2. OPD yang memiliki jumlah pending TLHP yang bersifat pengembalian keuangan paling besar. Berdasarkan data yang diperoleh, maka diketahui OPD yang memiliki pending TLHP yang bersifat pengembalian keuangan paling banyak adalah Sekretariat DPRD dengan nilai pending TLHP sebesar Rp.2.178.304.000,00. Informan yang dipilih adalah Sekretaris DPRD dan Kasubbag Administrasi Keuangan.

3. OPD yang memiliki temuan berulang untuk beberapa tahun. Terdapat temuan yang terus berulang selama beberapa tahun, yaitu pertanggungjawaban belanja bantuan hibah, bantuan sosial dan bantuan keuangan. Temuan ini terus terjadi setiap tahun dari tahun 2008 2015 dengan total nilai yang masih harus 
dipertanggungjawabkan sebesar Rp.6.863.329.985,00. Berdasarkan jenis temuan tersebut maka OPD yang bertanggungjawab adalah Badan Pengelolaan Kekayaan dan Aset Daerah (BPKAD). Informan yang dipilih adalah Sekretaris Badan dan Kepala Subbid Pengelolaan Belanja Tidak Langsung dan Pembiayaan Daerah.

Peneliti juga memilih Kasubbag Evaluasi dan Pelaporan Inspektorat Kabupaten Sanggau sebagai informan tambahan. Para informan ini dinilai dapat memberikan informasi mengenai proses penyelesaian TLHP. Pimpinan OPD merupakan pejabat tertinggi di instansinya yang memegang posisi paling strategis mengambil keputusan/kebijakan mengenai penyelesaian TLHP. Pejabat lain yang akan diwawancarai adalah pejabat pelaksana yang mengetahui secara teknis proses penyelesaian TLHP di instansinya, sehingga peneliti dapat memperoleh informasi yang lebih detail mengenai teknis operasional pelaksanaan TLHP di lapangan serta memperoleh data yang sama dengan sumber yang berbeda, baik itu mengkonfirmasi ulang hasil wawancara dengan pimpinan dan memperoleh bukti dokumentasi untuk memperkuat pernyataan yang ada.

Pedoman wawancara disusun sedemikian rupa sesuai dengan kegiatan pokok pada setiap fungsi manajemen. Pada fungsi perencanaan, maka peneliti mendapatkan informasi mengenai respon pimpinan terhadap temuan, diskusi intern yang dilakukan, strategi yang disusun, rencana kegiatan yang akan dilakukan, kebijakan yang telah dikeluarkan, dan penentuan sumber daya. Pada fungsi pengorganisasian, peneliti mendapatkan informasi mengenai alokasi sumber daya, pembagian tugas, pendelegasian wewenang, dan koordinasi yang dilakukan. Pada fungsi pengarahan, peneliti mendapatkan informasi mengenai upaya yang dilakukan pimpinan untuk menggerakkan tim dan memberikan tugas serta penjelasan kepada bawahan. Pada fungsi pengendalian, peneliti memperoleh informasi mengenai tindakan evaluasi dan koreksi yang dilakukan.

Dalam proses analisis data, peneliti berpedoman pada analisis data menurut Creswell (2014), yaitu dimulai dengan menyiapkan dan mengorganisasi data, yaitu hasil wawancara, pengamatan dan telaah dokumen. Langkah berikutnya adalah mereduksi data menjadi tema dengan melakukan pengkodean maupun peringkasan kode. Langkah terakhir adalah menyajikan data dalam bentuk pembahasan. Langkah-langkah yang dilakukan dalam penelitian ini, yaitu mengumpulkan data dari hasil wawancara dengan informan dan dokumen pendukung lainnya yang diperoleh dari hasil pengamatan maupun dokumentasi untuk meyakinkan kebenaran data yang diperoleh. Langkah selanjutnya peneliti membaca keseluruhan isi transkrip wawancara secara keseluruhan mencoba menghubungkan antara data yang diperoleh dari hasil wawancara dengan hasil pengamatan dan dokumentasi untuk memperoleh informasi secara keseluruhan.

Untuk memperoleh keyakinan mengenai keabsahan data, maka hasil wawancara dengan pimpinan instansi kemudian dibandingkan dengan hasil wawancara dengan pejabat teknis yang dapat memberikan informasi yang diperlukan 
terkait informasi yang sama. Informasi hasil wawancara juga dibandingkan dengan dokumen pendukung lainnya seperti peraturan/kebijakan, notulen rapat, surat tugas, surat-surat, laporan dan dokumen lainnya yang berhubungan dengan permasalahan yang dikaji. Informasi yang diperoleh dari hasil wawancara dengan Kasubbag Evaluasi dan Pelaporan selaku informan tambahan berupa informasi mengenai upaya pelaksanaan TLHP baik yang dilakukan oleh auditi maupun pemerintah daerah secara umum, informasi ini juga digunakan sebagai pembanding dengan hasil wawancara dengan pihak OPD. Peneliti meneliti kembali data kasar yang telah diperoleh, meringkasnya dan mengelompokkannya berdasarkan kesesuaian masalah sesuai dengan tahapan fungsi-fungsi manajemen, yaitu perencanaan (planning), pengorganisasian (organizing), pengarahan (directing), dan pengendalian (controlling). Selanjutnya Peneliti menyajikan data dalam bentuk deskripsi terhadap proses penyelesaian TLHP yang dilakukan OPD dan mengidentifikasi penyebab belum optimalnya penyelesaian TLHP di Pemerintah Kabupaten Sanggau.

\section{HASIL DAN PEMBAHASAN}

\section{Proses Tindak Lanjut Hasil Pemeriksaan}

Setiap organisasi auditi di Pemerintah Kabupaten Sanggau telah melalui tahapan manajemen dalam penyelesaian TLHP. Berdasarkan hasil temuan yang diperoleh, setiap OPD telah merasakan manfaat pemeriksaan bagi perbaikan kinerja organisasinya. Masing-masing OPD memberikan respon terhadap laporan hasil pemeriksaan yang diterimanya dengan melakukan berbagai upaya penyelesaian TLHP. Langkah awal yang dilakukan masingmasing OPD tidak selalu sama dengan OPD lainnya. Rapat internal begitu menerima LHP dilakukan oleh BPKAD dan DIKBUD, sedangkan pada Sekretariat DPRD, pimpinan cenderung melakukan diskusi langsung dengan pegawai yang bertanggung jawab pada permasalahan terkait. Masing-masing OPD mempunyai kewenangan sendiri dalam menentukan langkah-langkah yang paling efektif bagi organisasinya, demikian juga dengan pembentukan tim Ad Hoc seperti yang telah dihimbau oleh Inspektorat. Tim Ad Hoc merupakan tim khusus yang bertanggung jawab menyelesaikan TLHP di instansinya. BPKAD telah membentuk dan memfungsikan tim Ad Hoc dalam kegiatan penyelesaian TLHP, sementara Dinas Pendidikan dan Kebudayaan meskipun telah membentuk tim Ad Hoc namun belum berfungsi dengan baik, praktek penyelesaian TLHP masih bersifat tradisional yaitu dilimpahkan ke bidang tertentu sebagai penanggung jawab. Sekretariat DPRD malah belum membentuk tim Ad Hoc padahal keberadaan tim Ad Hoc sangat penting untuk membantu percepatan penyelesaian TLHP karena akan memudahkan proses koordinasi dengan berbagai pihak. Dari hasil pengamatan peneliti berdasarkan informasi yang diperoleh diketahui bahwa belum ada keseragaman dalam proses penyelesaian TLHP di OPD Pemerintah Kabupaten Sanggau.

OPD di Kabupaten Sanggau belum menetapkan tujuan dan target waktu penyelesaian TLHP secara eksplisit. Hal ini dikarenakan pimpinan OPD tidak ingin memberikan penekanan kepada 
pegawainya, OPD tidak dapat memprediksi waktu yang diperlukan untuk melakukan kegiatan tertentu, dan pimpinan OPD memberikan kebijakan penyelesaian TLHP yang disesuaikan dengan sifat penyelesaiannya. Dokumen perencanaan sebagai arsip penting yang akan bermanfaat sebagai panduan dalam pelaksanaan kegiatan TLHP, oleh sebab itu perlu didokumentasikan dengan baik. Bentuk dokumen perencanaan OPD di Kabupaten cukup bervariasi antar OPD, untuk hasil temuan terhadap laporan keuangan Pemerintah Kabupaten Sanggau disusun dalam bentuk Rencana aksi (action plan) sesuai permintaan BPK, namun untuk temuan pada masing-masing OPD memiliki bentuk tertulis tersendiri baik dalam bentuk notulen rapat maupun disposisi surat. Dalam pelaksanaan kegiatan tertentu diperlukan panduan yang rinci dalam bentuk aturan hukum. Dengan adanya Peraturan akan memberikan kejelasan pelaksanaan tugas dan konsekuensinya. Sampai saat ini di Pemerintah Kabupaten Sanggau belum memiliki aturan khusus mengenai penyelesaian TLHP sehingga pelaksanaan di OPD belum seragam, tidak ada panduan pelaksanaan, dan tidak ada kejelasan pemberian sanksi.

Pembagian tugas dan pendelegasian wewenang merupakan pelaksanaan fungsi pengorganisasian (organizing). Untuk pembagian tugas yang dilaksanakan pada instansi di Pemerintah Kabupaten Sanggau berdasarkan bidang tugas masing-masing sesuai dengan Susunan Organisasi, Tugas, Fungsi, dan Tata Kerja (SOTK) Instansi masing-masing ataupun diserahkan kepada Pejabat Pelaksana Teknis Kegiatan (PPTK) yang bertanggung jawab terhadap kegiatan yang menjadi temuan. Bagi yang telah membentuk tim Ad Hoc maka pembagian tugas seperti yang diuraikan dalam SK pembentukan tim. Ada pula OPD yang memberikan tugas kepada individu/bidang tertentu untuk mengumpulkan bukti TLHP dengan melakukan koordinasi dengan bidang lainnya dalam intern instansi. Pembagian tugas telah dirasakan cukup adil oleh para pelaksana. Setiap orang yang diberi kepercayaan menyelesaikan TLHP disesuaikan dengan bidang tugasnya masingmasing. Pimpinan OPD juga memberikan kewenangan sesuai dengan batasan tertentu.

OPD di Kabupaten Sanggau telah melakukan proses komunikasi dan koordinasi melalui forum rapat, surat maupun bertemu secara langsung. Koordinasi dilaksanakan dengan pihak intern maupun ekstern instansi. Pada proses koordinasi intern instansi ditemui adanya respon yang lambat karena kesibukan operasional instansi seharihari. Untuk proses koordinasi dengan pihak eksternal OPD mengalami kesulitan dalam proses penagihan kepada pihak ketiga karena perasaan sungkan pelaksana dan keengganan dari pihak ketiga untuk menyelesaikan kewajibannya. Cepat atau lambatnya penyelesaian TLHP sangat bergantung dari respon berbagai pihak, namun OPD tetap berusaha melakukan berbagai upaya terbaik untuk segera menyelesaikan temuan rekomendasi pemeriksaan yang menjadi tanggung jawab pada organisasinya.

Fungsi pengarahan (directing) menitikberatkan pada cara pimpinan menggerakkan bawahannya untuk dapat 
menyelesaikan tugas-tugas yang diberikan. Pada OPD pemerintah Kabupaten Sanggau, peran pimpinan adalah sebagai pemberi arahan dan pengambil keputusan jika terdapat kendala-kendala yang memerlukan otoritas pimpinan, namun jika pejabat teknis yang diberi tanggung jawab penyelesaian TLHP dapat mengatasinya maka pimpinan hanya sebatas mengawasi saja. Media komunikasi antara pimpinan OPD dan pegawai dapat melalui disposisi surat, rapat, maupun perbincangan pribadi dengan pejabat teknis terkait. Terdapat pemahaman yang sama antara pimpinan dan pejabat teknis yang menangani TLHP terhadap tugastugas penyelesaian TLHP. Para pegawai telah memahami dengan baik tanggung jawab yang diberikan oleh pimpinan, namun pimpinan belum mampu memberikan motivasi kepada pegawai. Berdasarkan informasi yang diperoleh diketahui bahwa sistem reward dan punishment belum dilaksanakan di Pemerintah Kabupaten Sanggau.

Fungsi pengendalian (controlling) meliputi kegiatan evaluasi yang dilakukan oleh OPD terhadap keberhasilan pelaksanaan tugas-tugas yang diberikan kepada individu-individu yang diberi tanggung jawab. Kegiatan evaluasi dilakukan melalui forum rapat maupun melalui laporan pejabat teknis terkait kepada pimpinan instansi. Kegiatan evaluasi meskipun tidak diagendakan secara rutin, namun tetap dilakukan sebagai bentuk pemantauan terhadap perkembangan penyelesaian TLHP yang terjadi pada instansi masing-masing karena akan dilaporkan ke unit pengawasan maupun Kepala Daerah. Setelah melakukan evaluasi maka OPD mengidentifikasi kendala- kendala yang mereka alami dalam penyelesaian TLHP serta berusaha untuk mengatasi setiap kendala yang ada. Kendala yang dialami OPD dalam melakukan evaluasi berhubungan dengan tahapan manajemen sebelumnya, yaitu pada proses perencanaan belum menetapkan target yang jelas sehingga tidak ada standar/indikator keberhasilan untuk menilai hasil yang telah dicapai.

\section{Upaya Pemerintah Kabupaten Sanggau Mengoptimalkan Penyelesaian TLHP}

Pemerintah Kabupaten Sanggau telah melakukan berbagai upaya dalam proses penyelesaian TLHP antara lain dengan membentuk Majelis Pertimbangan Tuntutan Perbendaharaan dan Tuntutan Ganti Rugi (TPTGR). Tujuan dibentuknya Majelis Pertimbangan TPTGR adalah untuk pengamanan dan penyelamatan terhadap kerugian keuangan dan barang milik daerah akibat perbuatan melanggar hukum atau kelalaian seseorang. Dalam menjalankan tugasnya, Majelis Pertimbangan TPTGR dibantu oleh Tim Sekretariat Majelis Pertimbangan TPTGR dalam menangani administrasi dan kesekretariatan.

Beberapa upaya yang telah dilakukan Majelis Pertimbangan TPTGR dalam penyelesaian kerugian daerah, antara lain menetapkan temuan yang terbukti menimbulkan kerugian daerah melalui Surat Keputusan yang ditandatangani oleh Kepala Daerah sebagai kerugian daerah. Majelis Pertimbangan TPTGR juga telah menyusun teknis penagihan untuk beberapa kasus kerugian daerah. Dari hasil penelusuran dokumen ditemukan bahwa pelaksanaan pembayaran angsuran oleh individu yang 
terutang tidak sesuai dengan teknis penagihan yang telah ditentukan. Upaya Majelis TPTGR dalam melakukan penagihan terhadap pihak-pihak yang berkewajiban menyelesaikan TLHP masih dengan upaya damai. Majelis TPTGR belum sampai melakukan upaya paksa, seperti pemotongan gaji jika yang bersangkutan merupakan pegawai negeri sipil maupun anggota DPRD atau melakukan penyitaan aset. Salah satu tugas dari Majelis Pertimbangan TPTGR adalah mengajukan usul penghapusan temuan bagi temuantemuan yang sudah tidak dapat ditindaklanjuti, namun berdasarkan hasil penelitian sampai saat ini Pemerintah Kabupaten Sanggau belum pernah mengusulkan penghapusan temuan.

Selain membentuk Majelis Pertimbangan TPTGR, dalam rangka upaya penyelesaian TLHP Pemerintah Kabupaten Sanggau juga telah membentuk tim tindak lanjut hasil pemeriksaan BPK. Tim TLHP BPK bertugas melaksanakan rapat pembahasan LHP BPK, menindaklanjuti rekomendasi dalam LHP BPK sesuai dengan bidang tugas masingmasing, memberikan jawaban atau penjelasan tentang tindak lanjut atas rekomendasi dalam LHP dan menyampaikan dokumen pelaksanaan tindak lanjut kepada BPK, dan melaporkan kemajuan pelaksanaan TLHP BPK kepada Bupati Sanggau. Pada pelaksanaannya rapat tim TLHP BPK dilaksanakan bersamaan dengan rapat monev dengan Kepala Daerah yang dilaksanakan secara insidentil pada saat menerima LHP BPK.

Pemerintah Kabupaten Sanggau juga telah menghimbau agar masing-masing Organisasi Perangkat Daerah (OPD) membentuk Tim Ad Hoc penyelesaian TLHP, yaitu tim khusus yang menangani penyelesaian TLHP pada masing-masing OPD. Tim Ad Hoc bertanggung jawab membuat komitmen bersama melalui penentuan target dan waktu dalam menyelesaikan TLHP. Melalui Tim Ad Hoc diharapkan akan memudahkan koordinasi antara instansi dan lembaga pengawasan maupun dengan pihak ketiga. Berdasarkan hasil temuan di lapangan terhadap ketiga OPD yang menjadi objek pemeriksaan dan konfirmasi dari Inspektorat maka diketahui bahwa masih banyak OPD yang belum membentuk tim Ad Hoc.

Dari hasil pengamatan peneliti selama beberapa waktu di kantor Inspektorat, terlihat aktivitas Inspektorat selaku lembaga pengawasan daerah dalam menanggapi LHP BPK yang baru diterima. Beberapa upaya untuk mempercepat penyelesaian TLHP yang dilakukan oleh Inspektorat, antara lain dengan memberikan penegasan pelaksanaan TLHP kepada SKPD melalui surat teguran maupun surat perintah pelaksanaan TLHP, kemudian Inspektorat juga menghimpun semua temuan yang ada dan melakukan pemantauan atas temuan-temuan tersebut, terhadap temuan-temuan yang signifikan Inspektorat mengundang OPD serta mengundang pihak ketiga yang mempunyai kewajiban penyelesaian TLHP untuk membahas penyelesaiannya. Dalam pertemuan dengan OPD maupun pihak ketiga terkait akan dibicarakan mengenai komitmen yang bersangkutan, khususnya yang berkaitan dengan pengembalian keuangan. Komitmen ini terkait dengan kesediaan OPD atau pihak ketiga menyelesaikan kewajibannya dalam kurun 
waktu tertentu. Pernyataan komitmen dapat berupa ditandatanganinya Surat Tanggung Jawab Mutlak (SKTJM) atau melakukan penyetoran kembali ke kas daerah terhadap kerugian daerah yang telah diidentifikasi.

Berbagai upaya telah dilakukan Pemerintah Kabupaten Sanggau dalam rangka melaksanakan tindak lanjut hasil pemeriksaan BPK, namun upaya-upaya tersebut masih belum optimal karena ada beberapa permasalahan yang ditemukan, baik yang terjadi di tingkat OPD maupun di tingkat pemerintah daerah. Bagian berikutnya akan dibahas mengenai permasalahan yang menyebabkan TLHP belum optimal.

\section{Penyebab Belum Optimalnya Penyelesaian TLHP}

Berdasarkan proses penyelesaian Tindak Lanjut Hasil Pemeriksaan yang dilakukan oleh OPD melalui analisis pelaksanaan fungsifungsi manajemen yang telah dibahas sebelumnya, maka peneliti mengidentifikasi beberapa penyebab belum optimalnya penyelesaian TLHP di Pemerintah Kabupaten Sanggau berdasarkan kelemahan-kelemahan yang ditemukan dalam tahapan-tahapan manajemen OPD maupun Pemerintah Daerah secara keseluruhan.

1. Belum Tersedianya Kebijakan Khusus tentang TLHP

Berdasarkan hasil temuan dalam proses penyelesaian TLHP di Pemerintah Kabupaten Sanggau diketahui bahwa belum ada kebijakan khusus yang mengatur pelaksanaan TLHP. Panduan yang digunakan selama ini berupa peraturan perundangan dari pusat yang mengatur hal-hal umum saja, sedangkan banyak hal-hal khusus yang perlu diatur lebih detail sesuai dengan kondisi di daerah. Hal-hal khusus yang perlu diatur secara detail, antara lain mengenai prosedur penyelesaian TLHP di daerah, cara menangani masalah-masalah umum, maupun sanksi yang akan diberikan kepada pihak-pihak yang lalai.

Dari hasil penelitian diperoleh informasi bahwa belum semua OPD membentuk tim Ad Hoc, OPD tidak membuat rencana aksi (action plan), serta tidak ada pemberian sanksi terhadap pihak yang melakukan kelalaian. Hal-hal tersebut terjadi karena tidak adanya aturan hukum yang mengatur secara tegas mengenai ketentuan penyelesaian TLHP. Setiap OPD di Pemerintah Kabupaten Sanggau telah memiliki mekanisme sendiri dalam proses penyelesaian TLHP yang tidak sama dengan OPD lainnya. Salah satu ketidakseragaman yang terjadi adalah belum semua OPD membentuk tim Ad Hoc, yaitu sebuah tim khusus yang menangani penyelesaian TLHP di instansinya. Keberadaan tim Ad Hoc akan memberikan kemudahan bagi instansi dalam pembagian tugas dan melakukan koordinasi lintas sektoral. Penerapan di Pemerintah Provinsi dan mulai ditiru di daerah menunjukkan bahwa tim Ad Hoc bermanfaat untuk proses penyelesaian TLHP yang lebih efektif, namun sayangnya belum semua OPD di Kabupaten Sanggau membentuk tim Ad Hoc karena tidak adanya aturan hukum yang mengatur hal ini secara tegas.

Pada tahap awal perencanaan, OPD di Pemerintah Kabupaten Sanggau tidak membuat rencana aksi (action plan) sebagai dokumen perencanaan. BPK menyarankan agar auditi menyusun sebuah rencana aksi (action plan) yaitu sebuah dokumen yang 
berisi ringkasan hasil temuan, rekomendasi hasil pemeriksaan, rencana kegiatan yang akan dilakukan, serta target waktu yang diperlukan. Dokumen ini berguna sebagai dasar pelaksanaan kegiatan-kegiatan dan sebagai bahan melakukan evaluasi. Rencana aksi (action plan) menjadi salah satu format yang efektif sebagai bentuk dokumen perencanaan karena mengandung ringkasan yang penting sebagai panduan pelaksanaan kegiatan. Rencana aksi (action plan) TLHP sebagai sarana untuk memudahkan dilakukannya pemantauan atas pelaksanaan TLHP, salah satunya adalah mencantumkan target waktu yang bisa mengingatkan pelaksana untuk segera menyelesaikannya. Penentuan target waktu diperlukan sebagai ukuran keberhasilan dalam melakukan suatu kegiatan. Berdasarkan hasil penelitian ditemukan bahwa OPD di Pemerintah Kabupaten Sanggau belum menetapkan target waktu dalam menyelesaikan TLHP.

Dari hasil penelitian juga diketahui bahwa belum ada sanksi yang tegas bagi instansi ataupun individu yang tidak menyelesaikan TLHP di lingkungan Pemerintah Kabupaten Sanggau. Sanksi masih mengacu pada aturan yang bersifat umum, yaitu mengacu pada pemberian hukuman disiplin namun tindakan konkretnya belum pernah diberikan. OPD menghadapi kendala dalam melakukan penagihan pengembalian keuangan terhadap pihak ketiga dikarenakan terbatasnya daya paksa instansi. OPD hanya melakukan tindakan penagihan secara normatif, yaitu dengan mengirim surat pemberitahuan saja. OPD tidak dapat mengambil tindakan paksa terhadap pihakpihak yang tidak segera menyelesaikan TLHP karena tidak ada kewenangan tersebut dalam peraturan perundang-undangan. Dengan adanya aturan hukum maka keseragaman mekanisme penyelesaian TLHP dapat diatur serta memberi daya paksa instansi kepada pihak-pihak yang berkewajiban melaksanakan tindak lanjut.

2. Masalah Koordinasi

Berdasarkan hasil temuan penelitian, beberapa masalah yang terjadi dalam proses koordinasi di Pemerintah Kabupaten Sanggau yaitu terkait dengan lambatnya respon dari pihak lain serta kegiatan koordinasi dengan lembaga pengawasan yang belum intensif. Koordinasi intern instansi terkendala dengan kesibukan operasional instansi sehari-hari yang menyebabkan respon penyelesaian TLHP menjadi lambat untuk dipenuhi bahkan terjadi kecenderungan di OPD bahwa TLHP merupakan pekerjaan tambahan dan bukan prioritas. Penyelesaian TLHP merupakan tanggung jawab dari pekerjaan yang harus segera dikerjakan meskipun bukan merupakan tugas pokok pelaksana. Hal ini berhubungan dengan kedisiplinan dan prioritas dari individu terkait.

Koordinasi dengan pihak ekstern telah dilakukan, baik dengan unit pengelola teknis pada OPD lain maupun kontraktor melalui berbagai media yang ada, namun cepat atau lambatnya penyelesaian TLHP tergantung kepada respon mereka. Jika unit pengelola/kontraktor merespon dengan cepat maka penyelesaian TLHP secara keseluruhan juga akan cepat, namun tidak semua pihak merespon dengan cara yang sama. Pada akhirnya kembali pada aturan hukum yang tegas sangat diperlukan sebagai alat pengendali agar suatu proses dapat berjalan sebagaimana mestinya. Dari hasil 
temuan penelitian diketahui bahwa koordinasi antara OPD dan pihak lembaga pengawasan kurang intensif, khususnya yang berkaitan dengan rekomendasi yang sulit dilaksanakan. Dengan adanya koordinasi dengan lembaga pengawasan menunjukkan bentuk keseriusan OPD terhadap penyelesaian TLHP, di mana ada upaya OPD dalam mengatasi kendala-kendala yang dialaminya.

3. Pimpinan Belum Mampu Memberikan Motivasi

Pimpinan OPD telah berupaya menjalankan perannya dengan ikut terlibat dalam upaya penyelesaian TLHP, antara lain pimpinan memberi kepercayaan dan tanggung jawab kepada pegawai, memberi kesempatan konsultasi, memberikan solusi jika pegawai mengalami kesulitan, serta sebagai pengambil keputusan dan penanggung jawab terhadap keseluruhan kegiatan. Menurut Ruky (2002), seorang pimpinan dikatakan telah memimpin dengan efektif jika ia mampu mengarahkan pegawainya untuk mengerjakan seluruh pekerjaan sesuai dengan yang telah direncanakan sebelumnya untuk mencapai tujuan organisasi. Kurangnya keterampilan seorang pemimpin dalam membangkitkan dan memelihara motivasi kepada bawahannya menyebabkan penyelesaian TLHP menjadi belum optimal. Berdasarkan hasil analisis terhadap proses penyelesaian TLHP, pimpinan OPD di Pemerintah Kabupaten Sanggau dinilai belum optimal dalam menggerakkan pegawainya menuntaskan TLHP.

Salah satu bentuk pemberian motivasi pimpinan kepada pegawai adalah dengan menerapkan sistem reward dan punishment terhadap pegawai yang diberi tugas menyelesaikan TLHP. Dari hasil wawancara diperoleh informasi bahwa Pemerintah Kabupaten Sanggau belum menerapkan sistem reward dan punishment, tidak ada perbedaan perlakuan antara yang cepat mengerjakan dan yang lambat atau tidak mengerjakannya. Pada dasarnya setiap orang tentunya berkeinginan untuk meraih prestasi dan berusaha untuk mencapainya, namun hal utama yang diperlukan setiap orang adalah mendapat dorongan/ perangsang secara terus-menerus sehingga dalam melaksanakan pekerjaannya dengan tetap bersemangat, dengan demikian mereka dapat bekerja dengan segala daya dan upaya (Manulang, 2002). Setiap orang membutuhkan motivasi sebagai kebutuhan paling mendasar dalam bekerja (Donnelly, Gibson \& Ivancevich, 1995), oleh sebab itu pimpinan hendaknya dapat memberikan motivasi kepada bawahannya.

Reward merupakan salah satu cara untuk memberi motivasi kepada seseorang yang merupakan bentuk penghargaan karena suatu prestasi tertentu yang sudah dicapai orang tersebut. Tujuan diberinya reward yaitu agar seseorang bisa lebih giat lagi dalam meningkatkan kinerja yang telah dicapai (Nugroho, 2006). Demikian juga dengan punishment yang merupakan bentuk motivasi tapi dari sisi yang berbeda, yaitu sesuatu yang harus dihindari sehingga seseorang harus melakukan yang terbaik agar terhindar dari hal-hal yang tidak menyenangkan. Ivancevich, Konopaske \& Matteson (2006:226) mendefinisikan punishment sebagai tindakan memberi konsekuensi yang tidak menyenangkan atau tidak diinginkan sebagai hasil dari perilaku tertentu. Pemberian motivasi merupakan 
keterampilan manajerial yang harus dimiliki oleh seorang manajer yang baik (Silalahi, 2011 \& Grifin, 2004), oleh sebab itu pimpinan OPD perlu mengembangkan keterampilannya dalam memberikan motivasi kepada pegawai agar dapat menyelesaikan pekerjaannya dengan antusias. Jika setiap pegawai melakukan pekerjaan mereka dengan semangat tinggi, maka penyelesaian TLHP juga bisa optimal.

4. Kurangnya Komitmen Pimpinan

Kurangnya komitmen pimpinan secara tidak langsung membuat daya paksa instansi menjadi lemah. Selain komitmen pimpinan instansi, komitmen Kepala Daerah juga berperan besar dalam mendorong penyelesaian TLHP. Komitmen pimpinan dapat dilihat dari sikap pimpinan dalam membuat kebijakan, salah satu contohnya adalah dengan pemindahan pejabat/staf teknis yang belum menyelesaikan tanggung jawabnya untuk melaksanakan rekomendasi auditor. Jika pimpinan mempunyai komitmen yang kuat untuk menyelesaikan TLHP, maka setiap pejabat harus terlebih dahulu menyelesaikan rekomendasi auditor yang menjadi tanggung jawabnya sebelum menunaikan tugas di tempat yang baru. Kebanyakan temuan yang sulit diselesaikan adalah temuan-temuan yang sudah lama dikarenakan pejabat yang menanganinya telah pindah tugas, sehingga pejabat baru kesulitan menemukan dokumen atau permasalahan detailnya. Komitmen pimpinan juga terlihat dari peran pimpinan memberi perhatian khusus terhadap penyelesaian TLHP, baik itu membahas dalam suatu pertemuan maupun dalam memberikan dukungan-dukungan tertentu yang memberi kemudahan dalam penyelesaian TLHP.

Menurut Subanegara (2005), komitmen merupakan bentuk kesetiaan pimpinan maupun pegawai terhadap organisasinya. Jadi komitmen merupakan bentuk ikatan psikologis antara anggota dan organisasinya (Meyer \& Allen, 1997). Pegawai yang memiliki komitmen tinggi tentu akan berusaha memberikan sesuatu yang terbaik untuk mengembangkan organisasinya (Baron \& Greeberg, 2000). Komitmen seseorang akan terlihat dalam bentuk sikap dan perilaku (Darmawan, 2013). Dalam hal penyelesaian TLHP, pimpinan OPD dinilai belum memiliki komitmen yang tinggi. Hal ini terlihat dari pemindahan pejabat yang tidak mempertimbangkan kewajiban yang bersangkutan terhadap penyelesaian TLHP, belum memberikan penekanan kepada pegawai yang bertanggung jawab dalam penyelesaian TLHP, belum adanya kebijakan tertulis tentang penyelesaian TLHP, jarang membahas perkembangan TLHP saat pertemuan, dan belum menganggap penyelesaian TLHP sebagai prioritas karena lebih mementingkan kegiatan operasional yang lain.

Komitmen memberikan kekuatan (power) untuk melakukan yang terbaik bagi organisasi melalui semua skill kepemimpinan yang dimiliki oleh seseorang. Dengan adanya komitmen yang kuat dari pimpinan OPD dan Kepala Daerah, maka akan menimbulkan semangat bagi seluruh pegawai untuk mengikuti arahan dari pimpinannya. Komitmen yang kuat dari pimpinan juga secara tidak langsung memberi daya paksa bagi organisasi, baik melalui pemberian 
sanksi tertentu maupun ketegasan pimpinan dalam setiap kebijakan yang dibuatnya.

\section{Masalah Evaluasi}

Dari hasil temuan di lapangan, Pemerintah kabupaten Sanggau mengalami kesulitan dalam melakukan evaluasi dan belum melakukan evaluasi secara berkala terhadap perkembangan penyelesaian TLHP. Kesulitan dalam melakukan evaluasi yang dialami oleh OPD dikarenakan perencanaan yang disusun sebelumnya belum maksimal. Perencanaan bermanfaat sebagai standar pelaksanaan dan pengawasan (Usman, 2013), jadi jika sebelumnya dalam perencanaan tidak menentukan ukuran standar/indikator keberhasilan dalam pencapaian tujuan dan target penyelesaian TLHP secara jelas maka akan sulit melakukan evaluasi terhadap pencapaian yang diperoleh, apakah telah sesuai dengan rencana atau tidak.

OPD di Pemerintah Kabupaten Sanggau telah melakukan evaluasi terhadap perkembangan penyelesaian TLHP, namun tidak ada jadwal yang tetap. Evaluasi yang dilakukan secara berkala dapat bermanfaat untuk memantau perkembangan yang terjadi dan jika ada kendala maka dapat dengan segera dicari solusinya. Evaluasi dapat dilakukan dalam lingkungan intern OPD maupun dalam lingkup pemerintah kabupaten Sanggau secara keseluruhan, baik berupa penyampaian laporan tertulis maupun membahasnya bersama dalam forum rapat. Dengan ditentukannya jadwal evaluasi terhadap perkembangan TLHP, maka akan mendorong setiap pelaksana lebih serius menanggapi tanggung jawabnya terhadap penyelesaian TLHP.
6. Belum Optimalnya Peran Majelis Pertimbangan Tuntutan Perbendaharaan dan Tuntutuan Ganti Rugi

Majelis Pertimbangan TPTGR dibantu oleh Tim Sekretariat berperan dalam melakukan analisis kasus-kasus TPTGR yang ada di Kabupaten Sanggau dan mengambil tindakan-tindakan yang diperlukan sebagai upaya pengamanan aset daerah dan menyelamatkan kerugian keuangan daerah. Dari hasil temuan diketahui bahwa peran Majelis Pertimbangan TPTGR belum optimal di mana sejauh ini baru melakukan upaya damai dalam melakukan penagihan kerugian daerah kepada pihak-pihak yang bertanggung jawab sedangkan nilai kerugian berjumlah besar dan sudah sangat lama. Tidak ada tindakan tegas dari Majelis TPTGR dalam melakukan tindakan disiplin kepada pihak-pihak yang lalai memenuhi tanggung jawabnya.

Belum optimalnya Majelis Pertimbangan TPTGR dalam menjalankan fungsinya juga terlihat dari belum pernah dilakukan penghapusan temuan yang sulit dan sudah lama. Jika dilihat dari data yang ada maka masih terdapat temuan yang sudah lama dan tidak ada perkembangan status penyelesaiannya. Temuan-temuan yang sudah lama ini sulit diselesaikan karena beberapa rekomendasi sulit dilaksanakan karena sudah tidak relevan seiring berjalannya waktu maupun orang yang berkewajiban menindaklanjutinya sudah meninggal dunia atau sudah tidak diketahui keberadaannya. Yang berwenang menghapus temuan adalah lembaga pengawasan, namun tentunya perlu diusulkan oleh pihak auditi sesuai dengan persyaratan yang diperlukan. 
Majelis Pertimbangan TPTGR sangat berperan penting dalam percepatan penyelesaian TLHP karena memiliki otoritas dan wewenang yang kuat dan sah secara hukum. Majelis TPTGR juga perlu memberi pertanggungjawaban berupa laporan kepada Kepala Daerah yang selanjutnya meneruskannya kepada Menteri Dalam Negeri Cq. Direktur Jenderal Bina Administrasi Keuangan Daerah terkait perkembangan penyelesaian kasus kerugian Daerah. Majelis TPTGR perlu lebih cermat lagi dalam mempelajari setiap temuan kerugian daerah yang ada dan diperlukan komitmen yang kuat dari para majelis dalam mendukung berbagai upaya penyelesaian TLHP serta untuk proses penagihan dan pembebanan kerugian perlu dilakukan lebih intensif lagi. Untuk temuan-temuan yang sudah lama dan sulit diselesaikan, maka Majelis TPTGR dapat mengusulkan penghapusan temuan ke BPK sesuai dengan ketentuan yang berlaku.

\section{Kendala Teknis Lainnya}

Terdapat beberapa kendala teknis yang dialami oleh OPD di Pemerintah Kabupaten Sanggau yang menjadi penyebab penyelesaian TLHP belum optimal. Kendala teknis yang dialami oleh OPD di Pemerintah Kabupaten Sanggau, yaitu orang yang berkewajiban menyelesaikan TLHP sudah meninggal atau sudah pindah tugas dan tidak diketahui keberadaannya lagi serta faktor komitmen pribadi yang bersangkutan yang enggan untuk mengembalikan kerugian daerah. Kebanyakan temuan yang sulit ditindaklanjuti adalah yang berkaitan dengan pengembalian keuangan dan kesulitan menemukan dokumen administrasi yang sudah lama. Untuk temuan-temuan lama yang belum ditindaklanjuti maka perlu dilakukan penelusuran ulang yang terkadang sulit dilakukan karena orang-orang yang bertanggung jawab dan mengetahui permasalahannya sudah tidak berada di tempat dan banyak dokumen yang sudah hilang.

Untuk pengembalian keuangan daerah, pada dasarnya tergantung lagi kepada komitmen pribadi yang bersangkutan. Ada sebagian orang yang berusaha memenuhi kewajibannya dengan melakukan penyetoran sekaligus atau melalui cicilan, namun ada juga yang tidak mampu untuk membayar dan tidak mau membayar. Pemerintah Kabupaten Sanggau juga telah menetapkan teknis penagihan dan angsuran pembayaran ganti rugi untuk beberapa kasus tertentu, namun kepatuhan setiap orang menaati aturan ini juga berbeda-beda. Menurut pengalaman OPD terkadang menemui masalah ketika melakukan penagihan terhadap orang yang harus melakukan penyetoran kembali, di mana pegawai yang menagih mendapat respon tidak menyenangkan dari orang-orang yang ditagih. Meskipun sangat bergantung pada orang yang bersangkutan, namun OPD tetap harus berusaha semaksimal mungkin dalam melakukan tugasnya. Pemerintah Daerah juga perlu untuk memperhatikan hal ini dan memikirkan cara terbaik menghadapi setiap permasalahan yang ditemui.

Kendala teknis lainnya yang dihadapi oleh OPD, yaitu kesulitan memenuhi permintaan auditor yang terkait dengan perbedaan mekanisme atau format administrasi antara yang dimiliki oleh instansi auditi dan auditor. Setiap OPD memiliki kesulitan tersendiri dalam penyelesaian TLHP yang bisa 
disebabkan oleh pengendalian intern dalam instansi yang belum efektif, kuantitas maupun kualitas sumber daya manusia, ketersediaan sarana dan prasarana pendukung, dan sebagainya. Secara teknis sebelum penerbitan LHP, auditi diberikan kesempatan untuk memberikan penjelasan yang akan menjadi pertimbangan auditor menentukan kelayakan temuan tersebut yang akan dimuat di LHP. Karena itu, auditi harus lebih cermat dalam menanggapi hasil pemeriksaan BPK sebelum diterbitkan LHP sesuai dengan prosedur teknis agar tidak mengalami kesulitan dalam menindaklanjuti hasil temuan di masa mendatang.

Kendala-kendala yang dialami setiap OPD dalam penyelesaian TLHP tentunya perlu dicarikan solusi yang tepat. Kendala yang dialami OPD pada umumnya terkait dengan sulitnya penagihan kerugian negara terhadap pihak ketiga, temuan-temuan yang telah lama sehingga sulit untuk melakukan penelusuran, keberadaan orang yang bertanggung jawab terhadap temuan sulit untuk ditemui, maupun perbedaan mekanisme/format administrasi dengan auditor. OPD harus berusaha maksimal untuk mengatasi kendala tersebut baik itu dengan membentuk tim khusus untuk melakukan penelusuran dan penagihan maupun melakukan koordinasi dengan Inspektorat dan BPK. Untuk temuan yang tidak dapat ditindaklanjuti maka OPD dapat mengumpulkan bukti-bukti pendukung yang diperlukan untuk selanjutnya digunakan dalam pengajuan penghapusan temuan.

\section{SIMPULAN}

OPD di Pemerintah Kabupaten Sanggau telah melaksanakan proses penyelesaian Tindak
Lanjut Hasil Pemeriksaan dengan melaksanakan setiap tahapan/fungsi manajemen sebagai respon dari rekomendasi hasil pemeriksaan BPK. Hasil penelitian menemukan bahwa terdapat kelemahan dalam proses penyelesaian TLHP yang dilakukan Pemerintah Kabupaten Sanggau yang menyebabkan belum optimalnya penyelesaian TLHP. Kelemahankelemahan yang ditemukan peneliti, yaitu pertama, belum tersedianya kebijakan khusus tentang TLHP sehingga para pelaksana tidak memiliki panduan dalam pelaksanaan kegiatan, setiap OPD mengambil kebijakannya masing-masing dan tidak ada keseragaman pola penyelesaian TLHP di Pemerintah Kabupaten Sanggau, serta tidak ada ketegasan mengenai pemberian sanksi bagi pihak yang lalai memenuhi kewajibannya.

Kedua, lambatnya respon pihak lain dalam pelaksanaan proses koordinasi dan belum intensifnya koordinasi antara OPD dan lembaga pengawasan. Koordinasi intern instansi terkendala oleh kesibukan operasional instansinya. Lambatnya respon pihak ketiga dikarenakan kurangnya rasa tanggung jawab dan kedisiplinan individu yang bersangkutan serta tidak adanya daya paksa instansi melakukan proses penagihan. Belum intensifnya koordinasi antara OPD dan lembaga pengawasan dalam menyelesaikan temuan-temuan yang sulit ditindaklanjuti menunjukkan tingkat keseriusan menyelesaikan TLHP yang masih rendah.

Ketiga, pimpinan belum mampu memberikan motivasi kepada para pegawai dalam melakukan penyelesaian TLHP. Sistem reward dan punishment belum diterapkan di Pemerintah Kabupaten Sanggau sehingga 
para pegawai tidak memiliki dorongan semangat dalam bekerja. Keempat, kurangnya komitmen pimpinan yang terlihat dari kebijakan mutasi pegawai yang tidak mempertimbangkan kewajiban TLHP yang belum selesai, belum memberikan penekanan dan sanksi kepada pegawai yang lalai melaksanakan tugasnya, belum adanya kebijakan tertulis yang mengatur pelaksanaan TLHP, jarang membahas perkembangan TLHP pada saat pertemuan, dan lebih mementingkan kegiatan operasional lainnya dari pada penyelesaian TLHP.

Kelima, kesulitan dalam melakukan proses evaluasi dan evaluasi yang tidak dilaksanakan secara berkala. Kesulitan dalam melakukan evaluasi dikarenakan perencanaan yang belum matang, yaitu tidak menentukan indikator keberhasilan berupa tujuan dan target waktu penyelesaian TLHP. Akibatnya sulit untuk mengukur keberhasilan kegiatan, apakah telah sesuai dengan rencana atau tidak. Evaluasi yang tidak dilakukan secara berkala menyebabkan kedisiplinan pegawai dalam melaporkan perkembangan TLHP rendah dan cenderung kurang serius menanggapi TLHP karena tidak selalu terpantau oleh pimpinan.

Keenam, belum optimalnya peran Majelis Pertimbangan TPTGR dalam menangani kasus kerugian daerah. Majelis Pertimbangan TPTGR sebagai lembaga yang memiliki kewenangan secara hukum belum melakukan tindakan yang tegas kepada pihak-pihak yang lalai memenuhi kewajibannya serta belum pernah mengusulkan penghapusan temuan yang sudah tidak bisa ditindaklanjuti.
Ketujuh, belum optimalnya penyelesaian TLHP disebabkan oleh kendala-kendala teknis yang dihadapi oleh OPD. Kendalakendala yang dihadapi OPD antara lain terkait temuan-temuan yang sudah lama di mana dokumen pendukung sulit ditemukan dan orang yang menanganinya telah pensiun, meninggal, atau telah pindah tugas ke tempat lain. Kendala lainnya yang dihadapi oleh OPD terkait dengan kewajiban pihak ketiga mengembalikan kerugian daerah di mana sebagian ada yang sudah meninggal, tidak diketahui keberadaannya, dan rasa enggan untuk menyetorkan kewajibannya ke kas daerah. Kendala berikutnya adalah yang berkaitan dengan kesulitan memenuhi format administrasi BPK yang disebabkan oleh perbedaan mekanisme antara OPD dan BPK selama ini sehingga dibutuhkan waktu yang lama untuk melakukan proses penyesuaian.

\section{DAFTAR PUSTAKA}

Aikins, S. (2012). Determinants of Auditee Adoption of Audit Recommendations: Local Government Auditor's Perspectives. Journal of Public Budgeting, Accounting \& Financial Management, 24 (2), 195-220.

Arini, I.G.A.A.K. (2014). Analisis Peran Manajer Dalam Tindak Lanjut Laporan Hasil Pemeriksaan Oleh Satuan Pemeriksaan Intern di RSUP Sanglah Denpasar Tahun 2012. Tesis, Universitas Indonesia, Program Studi Kajian Administrasi Rumah Sakit, Fakultas Kesehatan Masyarakat, Jakarta.

Baron, R. A., \& Greeberg, J. (2000). Behavior in Organizations (7th Edition). New Jersey: Prentice Hall, Inc. 
BPKP. (2009). Modul Pembentukan Auditor Ahli Auditing. Jakarta: Pusat Pendidikan dan Pelatihan Pengawasan BPKP.

Creswell, J. (2014). Penelitian Kualitatif \& Desain Riset: Memilih di Antara Lima Pendekatan (Edisi Indonesia). Yogyakarta: Pustaka Pelajar.

Darmawan. (2013). Prinsip-Prinsip Perilaku Organisasi. Surabaya: Pena Semesta.

Donnelly, Gibson, \& Ivancevich. (1995). Fundamentals of Management (9th Edition). New York: Irwin INC.

Grifin, R. W. (2004). Manajemen (Edisi ke 7). Jakarta: Erlangga.

Hasibuan, M. (2014). Manajemen: Dasar, Pengertian, dan Masalah. Jakarta: PT. Bumi Aksara.

Ivancevich, K., \& Matteson. (2006). Perilaku Manajemen Dan Organisasi. Jakarta: Erlangga.

Junarlin. (2009). Evaluasi Atas Tindak Lanjut Hasil Pemeriksaan Oleh Inspektorat (Studi Kasus pada Inspektorat Provinsi Sulawesi Tenggara). Laporan Studi Kasus, Universitas Brawijaya, Program Magister Akuntansi, Pascasarjana Fakultas Ekonomi, Malang.

Kaelin, A. (2016). Auditing 101. Journal of Protective Coatings \& Linings, 33 (8), 1821.

Keating, G. (1995). The art of the follow-up. The Internal Auditor, 52 (2), 59.

Kementerian Pendayagunaan Aparatur Negara. (2005). Surat Edaran Menteri Pedayagunaan Aparatur Negara Nomor SE/02/M.PAN/01/2005 tentang Pelaksanaan Tindak Lanjut Hasil Pengawasan Intern Pemerintah. Jakarta.

Kementerian Pendayagunaan Aparatur Negara. (2009). Peraturan Menteri Negara Pendayagunaan Aparatur Negara Nomor 9 Tahun 2009 tentang Pedoman Umum Pelaksanaan,
Pemantauan, Evaluasi dan Pelaporan Tindak Lanjut Hasil Pengawasan. Jakarta.

Liu, J., \& Lin, B. (2012). Government Auditing and Corruption Control: Evidence from China's Provincial Panel Data. China Journal of Accounting Research, 5, 163186.

Loke, C.H., Ismail, S., \& Hamid, F.A. (2016). The perception of public sector auditors on performance audit in Malaysia: an exploratory study. Asian Review of Accounting, 24 (1), 90-104.

Manulang. M. (2002). Manajemen Sumber Daya Manusia Perusahaan. Bandung: PT Remaja Rosda.

Meyer, J.P., \& Allen, N. J. (1997). Commitment in The Work Place Theory Research and Application. California: Sage Publications.

Moleong, L. (2014). Metodologi Penelitian Kualitatif. Bandung: PT Remaja Rosda Karya.

Naeemullah, K., Muhammad, I.H., Muhammad, S., Uddin, M.N., \& Shafqat, $\mathrm{H}$. (2010). The managerial behavior of secondary school heads in punjab (pakistan). Educational Research and Reviews, 5 (4), 186-189.

Newport, M.G., \& Robert L.T. (1976). Management: Functions and Behavior. Dallas: Business Publications, Inc.

Nickels, W.G., McHugh, J.M., \& McHugh, S.M. (1997). Understanding Business (4 ed.). USA: McGraw Hill Comp, Inc.

Nugroho, B. (2006). Reward dan Punishment. Bulletin cipta karya, departemen pekerjaan umum edisi no 6/IV/ Juni 2006.

Pemerintah Republik Indonesia. (1945). Undang-Undang Dasar Negara Indonesia Tahun 1945. Jakarta.

Pemerintah Republik Indonesia. (2004). Undang-Undang Nomor 15 tahun 2004 tentang Pemeriksaan Pengelolaan 
Tanggungjawab Keuangan Negara. Sidik, A. (2009). Analisis Permasalahan Jakarta.

Tindak Lanjut Hasil Audit Aparat Pengawasan Internal Pemerintah Daerah (Studi Kasus pada Inspektorat Provinsi Nusa Tenggara Barat). Laporan Studi Kasus, Universitas Brawijaya, Program Magister Akuntansi, Pascasarjana Fakultas Ekonomi.

Qureshi, A.A., Afzal, S., Daud, I., \& Saleem, M.A. (2013). A comparative analysis of gender based management styles of software project managers. International Journal of Computer Applications, 71, (14).

Rucky, A. (2002). Manajemen Penggajian dan Pengupahan Untuk Karyawan Perusahaan. Jakarta: Gramedia Pustaka Utama.

Russell, J.P., \& Regel, T. (1996). After the quality audit: Closing the loop on the audit process. Quality Progres, 29 (6), 65.

Sari, D. (2013). Pengaruh SPIP, Implementasi Standar Akuntansi Pemerintahan, Penyelesaian Temuan Audit Terhadap Penerapan Prinsip-Prinsip Tata Kelola Pemerintahan yang Baik (Penelitian Pada Pemerintah Daerah Di Provinsi Jawa Barat Dan Banten). Simposium Nasional Akuntansi XVI. Manado.

Schneider, A. (2009). Informing The Audit Commite: Information and Reports Provided by Internal Audit. Internal Auditing, 24 (2), 24-32.

Silalahi, U. (2011). Asas-Asas Manajemen. Bandung: PT. Refika Aditama.

Stoner, J.A.F., \& Newport, E. (1982). Management (3th edition). Texas: Business Publications Inc

Subanegara. (2005). Diamond Head Drill \& Kepemimpinan dalam Manajemen Rumah Sakit. Yogyakarta: Andi Press.

Suryanto, A. (2015). Studi Keterlambatan Tindak Lanjut Temuan Hasil Pemeriksaan Inspektorat Daerah Kabupaten Kulonprogo D.I Yogyakarta dan Implementasi Manajerial. Tesis, Universitas Muhammadiyah, Program Magister Manajemen, Pascasarjana Fakultas Ekonomi.

Sutrisno, H. (1983). Metodologi Research. Yogyakarta: BPFE.

Terry, G. R. (1977). Principles of Management (7th edition). Homewood, Illinois: Richard D. Irwin.

Usman, H. (2013). Manajemen: Teori, Praktik, dan Riset Pendidikan (Edisi ke 4). Jakarta: PT Bumi Aksara. 